Research Report

\title{
IGF-I protects cortical neurons against ceramide-induced apoptosis via activation of the PI-3K/Akt and ERK pathways; is this protection independent of CREB and Bcl-2?
}

\author{
Sandrine Willaime-Morawek, Nicolas Arbez, Jean Mariani, Bernard Brugg* \\ Laboratoire Neurobiologie des Processus Adaptatifs (UMR 7102 CNRS and Univ. P. and M. Curie), 9 quai Saint Bernard, 75005 Paris, France
}

Accepted 18 September 2005

Available online 14 November 2005

\begin{abstract}
Current understanding of IGF-I-mediated neuroprotection implies the activation of phosphatidylinositol-3-kinase (PI-3K), which leads to the activation of Akt/Protein Kinase B. In non-neuronal cells, Akt phosphorylates and activates the transcription factor CREB, implicated in the transcription of the anti-apoptotic $b c l-2$ gene. This paper further analyses the anti-apoptotic IGF-I action in neurons. We show that IGF-I protects cortical neurons against ceramide-induced apoptosis. Ceramide decreases Akt phosphorylation during apoptotic process whereas a simultaneous treatment with IGF-I increases Akt phosphorylation. Analysis of the signal transduction pathways revealed that IGF-I induces CREB phosphorylation via PI-3K and ERK, whereas simultaneous ceramide and IGF-I treatment decreases CREB phosphorylation. Although an overexpression of Bcl-2 protects cortical neurons against ceramide-induced apoptosis, our data indicate that the Bcl-2 protein level is not modulated during IGF-I, ceramide and/or LY294002 treatment. In consequence, we demonstrated that IGF protects neurons against ceramide-induced apoptosis and that IGF-I protection involves the PI-3K/Akt and ERK pathways; this protection may be independent of CREB and Bcl-2.
\end{abstract}

(C) 2005 Elsevier B.V. All rights reserved.

Theme: Development and regeneration

Topic: Neuronal death

Keywords: Primary culture; Cortex; Signal transduction

Abbreviations: Ara-C, Cytosine arabinoside; BSA, Bovine serum albumin; CaMKIV, Calcium-calmoduline kinase IV; CAPP, Ceramide activated protein phosphatase; cer, $\mathrm{c}_{2}$-ceramide; CREB, CAMP-response element binding protein; ECL, Enhanced chemiluminescence; ERK, Extracellular signal regulated kinases; FCS, Fetal calf serum; HS, Horse serum; IGF-I, Insulin-like growth factor-I; JNK, Stress activated protein kinases/c-Jun N-terminal kinases; LY, LY 294002, PI-3K inhibitor; MAP kinase, Mitogen activated protein kinase; MTT, tetrazolium salt 3(4,5dimethylthiazol-2-yl)-2,5-diphenyltetrazolium bromide; PC12, Pheochromocytoma clone 12; PDK2, $\mathrm{PIP}_{3}$ dependent kinase 2; PI-3K, phosphatidylinositol-3-kinase; PKA, Proteine kinase A; PKB, Proteine

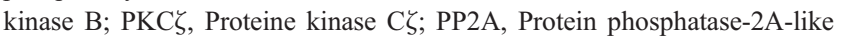
phosphatase; SDS-PAGE, Sodium dodecyl sulfate polyacrylamide gel electrophoresis

* Corresponding author. Fax: +331442726 69 .

E-mail address: bernard.brugg@snv.jussieu.fr (B. Brugg).

\section{Introduction}

Insulin-like Growth Factor-I (IGF-I) belongs to the somatomedin group of polypeptide hormones [12]. IGF-I has neuroprotective properties by reducing programmed death of motorneurons during development, after axotomy and spinal cord transection $[34,35,42]$. Intraventricular application of IGF-I has shown to attenuate neuronal cell loss after hypoxic-ischemic brain injury in adult rats $[22,56,57]$. In vitro studies revealed that IGF-I exerts its biological actions through a tyrosine kinase receptor, responsible for the phosphorylation of intracellular signal transduction proteins [59]. IGF-I-mediated neuroprotection is induced through the activation of the phosphatidylinositol-3-kinase (PI-3K), as demonstrated for cerebellar granule 
cells and sensory dorsal root ganglion cells $[1,33,39,50]$ leading to the phosphorylation and subsequent activation of Akt/Protein Kinase B [2,18,21,44]. Active Akt in turn can phosphorylate and thereby inactivate several cytoplasmic or nuclear targets such as the initiator caspase, caspase- $9[9,33]$, the proapoptotic protein $\mathrm{Bad}$ and the transcription factor FKHRL-1 [10,15,33]. A recent study in non-neuronal cells has demonstrated that Akt can also phosphorylate and activate the transcription factor CREB, implicated in the transcription of the antiapoptotic $b c l-2$ gene [49].

This report analyses the effects of the anti-apoptotic action of IGF-I on neuronal apoptosis using ceramide as an apoptotic inducer. Ceramide is a second messenger generated intracellularly by the sphingomyelinase-mediated cleavage of sphingomyelin $[23,29,38]$. Sphingomyelinase activity is strongly increased during developmental neuronal death in rat brain [54]. Increased ceramide levels are observed during apoptosis induced by growth factor-withdrawal in neuronally differentiated PC12 cells [32] or cortical neurons [62] and after ischemia in the gerbil hippocampus [41]. Furthermore, apoptosis can be induced by exogenous ceramide treatment of PC12 cells [20,24], mesencephalic [7], hippocampal [40] or cortical neurons [60]. Recently, we have shown that ceramide regulates pro-apoptotic MAP kinase pathways and that $\mathrm{JNK}$ and p38 activation is crucial in ceramide-induced neuronal apoptosis in primary cortical neurons $[60,61]$. Thus, the objective of this study is to evaluate the protective effects of IGF-I on ceramideinduced neuronal cell death in primary cortical neuronal cultures.

\section{Materials and methods}

\subsection{Materials}

\subsubsection{Drugs}

$\mathrm{C}_{2}$-ceramide ( $\mathrm{N}$-acetylsphingosine, Biomol Research Lab, Plymouth Meeting, PA, USA) was prepared as a 25$\mathrm{mM}$ stock in ethanol and incubated in the culture media. The specificity of $\mathrm{c}_{2}$-ceramide was evaluated by comparing its effects with those of $c_{2}$-dihydro-ceramide (Biomol Research Lab). This analogue is lacking the 4-5 trans double bond in the sphingosine moiety of $\mathrm{c}_{2}$-ceramide, and is unable to activate the sphingomyelin pathway in lymphocytes $[4,45]$ and neurons [7].

Insulin-like growth factor-I (Sigma, Saint Louis, MO, USA) was prepared as $0.1 \mathrm{M}$ acid acetic stocks at $0,05 \mathrm{mg}$ / $\mathrm{mL}$ and added to the culture media as described. LY294002 (Cell Signaling Technology, Ozyme, France) was prepared as DMSO stocks at $50 \mathrm{mM}$ and added to the culture media as described. ERK pathway inhibitor U0126 (Promega) was prepared as DMSO stocks at $10 \mathrm{mM}$ and added to the culture media as described.

\subsubsection{Antibodies}

We used Cell Signaling Technology rabbit antisera specifically directed towards phospho-Ser ${ }^{473}$ Akt diluted 1:1000, phospho-Ser ${ }^{133}$ CREB diluted 1:750 for Western blot or 1:500 for immunocytochemistry. We also used rabbit polyclonal antisera raised against synthetic peptides specific for Akt (phosphorylation-state independent; Cell Signaling Technology) diluted 1:1000, mouse monoclonal antisera raised against a recombinant Bcl-2 (Santa Cruz, Santa Cruz, CA, USA) diluted 1:1000. Phospho-ERK (P-ERK) diluted 1:1000, ERK diluted 1:750 and CREB diluted 1:1000 antibodies were all rabbit antisera purchased from Cell Signaling Technology.

\subsubsection{Mice}

The Swiss mice were purchased from Janvier (Le Genest-St-Isle, France). Bcl-2 transgenic mice were generated from our breading colony, from mice kindly given by Dr. Martinou, University of Geneva, Switzerland. Expression of Bcl-2 in these transgenic mice has been previously published [17,37]. Adequate measures were taken to minimize the number of animals used, pain or discomfort. All experiments conformed to French guidelines on the ethical use of animals and European Communities Council Directive of 24 November 1986 (86/609/EEC).

\subsection{Genotyping}

Genotyping for $b c l-2$ was performed by PCR using two primers to detect the human $b c l-2$ transgene: forward $5^{\prime}$ ATGAGCCTTGGGACTGTGAA-3', reverse 5'-GAAGACTCTGCTCAGTTTGG- $3^{\prime}$. Cycling parameters were 5 min at $94{ }^{\circ} \mathrm{C}$ for one cycle, $45 \mathrm{~s}$ at $94{ }^{\circ} \mathrm{C}, 45 \mathrm{~s}$ at $60{ }^{\circ} \mathrm{C}, 1$ min at $72{ }^{\circ} \mathrm{C}$ for a total of 40 cycles. PCR products were resolved on a $2 \%$ agarose gel.

\subsection{Primary cultures of mouse cortex}

Embryos were removed at day 14 from timed-pregnant Swiss mice (Janvier, Le Genest-St-Isle, France). The cortex was dissected, mechanically dissociated and plated on polyethyleneimine $(1 \mathrm{mg} / \mathrm{mL})$ coated culture wells, in Eagle's basal medium (Eurobio, Les Ulis, France), supplemented with $5 \%$ horse serum (HS; Eurobio) and 2.5\% fetal calf serum (FCS; Eurobio), at a density of $7 \times 10^{5} \mathrm{cells} / \mathrm{cm}^{2}$. After 2 days in culture the media was replaced with N5 medium [26] with $180 \mathrm{mg} / \mathrm{L}$ glucose and changed daily; FCS content was reduced to $1 \%$; Ara-C (cytosine arabinoside, $3 \mu \mathrm{M}$, Sigma, Saint Louis, MO, USA) was added to prevent astrocyte proliferation (our cultures were at least 95\% neuronal after this treatment), and MK-801 (1 $\mu \mathrm{M}$, Research Biochemicals International, Natick, MA, USA) to prevent excitotoxicity $[7,28]$.

Primary neuronal cultures taken from the $b c l-2$ transgenic mice were prepared using the cortex. The cortex from one embryo provides approximately $4 \times 10^{6}$ cells that we 
plated at a density of $7 \times 10^{5}$ cells $/ \mathrm{cm}^{2}$ in 96 well plates. Each culture was derived from an individual embryo, as genotyping was performed after putting the cells into culture.

\subsection{Ceramide treatment}

Embryonic cortical neurons cultivated in 5\% HS and $1 \%$ FCS, optimal conditions for their maturation and differentiation were insensitive to $c_{2}$-ceramide treatment. That is why we reduced serum content to $1 \%$ HS, 24 $\mathrm{h}$ before any ceramide treatment [7]. Thus, the effects seen were not due to partial serum deprivation but rather to specific treatment, since control cells were in the same serum conditions during the same time as the treated cells. The culture conditions (concentration and time course) under which $c_{2}$-ceramide provokes cell death were determined by a cell-viability test.

\subsection{Cell viability}

Cell viability was determined by counting viable cells after a ten-min treatment with bisbenzimide $(0.8 \mu \mathrm{g} / \mathrm{mL})$, Triton X-100 $(0.005 \%)$ or with the MTT assay (the conversion of the yellow tetrazolium salt [3(4,5-dimethylthiazol-2-yl)-2,5-diphenyltetrazolium bromide, MTT] to the purple formazan dye depends upon the mitochondrial activity [3,53]). The MTT assay was performed on neurons in $\mathrm{N} 5$ medium $1 \% \mathrm{HS}$, with MTT $(0.5 \mathrm{mg} / \mathrm{mL})$ for $4 \mathrm{~h}$ in a humidified atmosphere at $37{ }^{\circ} \mathrm{C}, 5 \% \mathrm{CO}_{2}$. The purple formazan salt was solubilized in $100 \mu \mathrm{L}$ of a solution containing $0.1 \mathrm{M} \mathrm{HCl}$ in isopropanol. The spectrophotometric absorbency of the samples was determined at a 560nm wave length.

\subsection{Transfections}

Transient transfection of primary cortical cultures was performed with LipofectAMINE 2000 (Invitrogen, Groningen, The Netherlands) as recommended by the manufacturer's protocol. Cells were transfected with $1 \mu \mathrm{g}$ of a plasmid encoding enhanced green fluorescent protein (pEGFP-N3; Clontech, Cambridge, UK). After $6 \mathrm{~h}$, the cultures were rinsed with fresh media. Transfection efficacy was $3-5 \%$ of the cells. After treatments, the cells were fixed as described for immunocytochemistry.

\subsection{Western blot analysis}

Cultured neurons were lysed in solubilization buffer (10 $\mathrm{mM}$ Tris- $\mathrm{HCl}, 50 \mathrm{mM} \mathrm{NaCl}, 1 \%$ Triton X-100, $30 \mathrm{mM}$ $\mathrm{Na}_{4} \mathrm{P}_{2} \mathrm{O}_{7}, 50 \mathrm{mM} \mathrm{NaF}, 5 \mu \mathrm{M} \mathrm{ZnCl}, 100 \mu \mathrm{M} \mathrm{Na} \mathrm{VO}_{4}, 1$ $\mathrm{mM}$ dithiothreitol, $5 \mathrm{nM}$ okadaic acid, $2.5 \mu \mathrm{g} / \mathrm{mL}$ aprotinin, $3.6 \mu \mathrm{M}$ pepstatin, $0.5 \mu \mathrm{M}$ phenylmethylsulfonyl fluoride, $0.5 \mathrm{mM}$ benzamidine, $5.3 \mu \mathrm{M}$ leupeptin) at $4{ }^{\circ} \mathrm{C}$. Insoluble materials were removed by centrifugation $(13,000 \mathrm{~g}$ for 20 min at $4{ }^{\circ} \mathrm{C}$ ), supernatants were isolated and the samples were stored at $-80{ }^{\circ} \mathrm{C}$. Proteins were dosed with the DC protein assay kit (Bio-Rad, Hercules, CA, USA). Cellextracts containing equivalent amounts of protein were boiled for $5 \mathrm{~min}$ in sample loading buffer. After a 10\% (15\% for Bcl-2 detection) SDS-PAGE, proteins were transferred to a polyvinylidene difluoride membrane (ICN Biochemicals, Costa Mesa, CA USA). The transfer was checked by Coomassie blue staining of the gels and the equal gel loading was confirmed by Ponceau red staining of the membranes. The transfer was also checked by the homogenous background of the blots after revelation. Non-specific sites were blocked with $5 \%$ skimmed dried milk for $2 \mathrm{~h}$. Blots were then incubated overnight at $4{ }^{\circ} \mathrm{C}$ with primary antibodies against the phosphorylated form of the kinases, in 5\% Bovine Serum Albumin (BSA). They were then incubated with horseradish peroxidase-conjugated secondary antibodies in 5\% skimmed dried milk for $1 \mathrm{~h}$. The revelation was processed with enhanced chemiluminescence substrate (Amersham, UK). The blots were stripped with $0.1 \mathrm{M}$ glycine- $\mathrm{HCl}(\mathrm{pH} 2.8)$ twice for $30 \mathrm{~min}$ at $60{ }^{\circ} \mathrm{C}$ and $\operatorname{SDS} 2 \%$ for $10 \mathrm{~min}$, followed by saturation in $5 \%$ skimmed dried milk overnight at $4{ }^{\circ} \mathrm{C}$. They were then incubated with the primary antibodies detecting both phosphorylated and non-phosphorylated forms of the kinases, in 5\% skimmed dried milk, followed by incubation with the secondary antibody for $1 \mathrm{~h}$, and revealed with the ECL kit as described above. Quantification was processed using the Densylab software (Microvision Instruments).

\subsection{Immunocytochemistry}

After $c_{2}$-ceramide treatment, cells were fixed with PBS (Phosphate Buffer Saline) containing 2\% paraformaldehyde for $40 \mathrm{~min}$, and then incubated with methanol/ acetone solution $(50 / 50)$ for $10 \mathrm{~min}$ at $4{ }^{\circ} \mathrm{C}$. After washing three times with PBS, plates were treated with blocking buffer containing FCS 10\%, BSA 3\% Triton X-100 0.2\% in PBS for $30 \mathrm{~min}$. Polyclonal antibody raised against phosphorylated CREB was incubated overnight at $4{ }^{\circ} \mathrm{C}$ in PBS containing $1 \%$ BSA and $0.2 \%$ Triton X-100. Plates were rinsed 3 times in PBS and then incubated with an anti-rabbit Cy3-conjugated antibody (1:2000) for $1.5 \mathrm{~h}$ in PBS containing BSA $1 \%$, Triton X-100 0.2\%. After counterstaining with Hoechst, cells were mounted under coverslips using Vectashield (Vector Abcys, France).

\section{Results}

\subsection{IGF-I protects cortical neurons against ceramide-induced apoptosis}

The effect of IGF-I on ceramide-induced apoptosis was examined in primary cortical neurons. Cortical neurons 
were treated after a 5-day maturation period in vitro with $\mathrm{c}_{2}$ ceramide $(40 \mu \mathrm{M})$ and IGF-I $(10 \mathrm{ng} / \mathrm{mL})$, then assayed for cell viability at various times after treatment using the MTT metabolism assay (Fig. 1A). By measuring survival, we have shown that IGF-I inhibited ceramide-induced apoptosis. From $16 \mathrm{~h}$ until $48 \mathrm{~h}$ of treatment, co-treatment of ceramide with IGF-I resulted in a survival increase from $61 \%$ to $97 \%$ at $24 \mathrm{~h}$, and from $50 \%$ to $84 \%$ at $48 \mathrm{~h}$ (Fig. 1A). Furthermore, dose dependence analysis (Fig. 1B) reveals that a dose of $5 \mathrm{ng} / \mathrm{mL}$ completely protects cortical neurons from ceramide-induced apoptosis.

GFP transfection of the neurons allowed determination of their morphology during treatment. After $24 \mathrm{~h}$ of ceramide treatment, apoptotic features such as neurite fragmentation and nuclear condensation and fragmentation were observed (Figs. 1D and H). In IGF-I treated cells, GFP labeling visualized intact neurons with long neurites, as observed in the untreated control cells (Figs. 1C and E). When cells were co-treated with ceramide and IGF-I, cells looked healthy similar to control cells (Fig. 1F). In conclusion, we show that IGF-I protects neurons against ceramide-induced apoptosis, and that such protected neurons show no signs of nuclear fragmentation and condensation or neurite fragmentation.

\subsection{Ceramide decreases P-Akt, whereas IGF-I increases it, even in presence of ceramide}

In non-neuronal cells, ceramide has been shown to inhibit the PI-3K/Akt pathway. To determine whether this pathway is modulated during ceramide-induced neuronal apoptosis, Western blots of cellular extracts were performed with antibodies directed against the phosphorylated form of Akt. As ceramide inhibits Akt by promoting dephosphorylation of serine 473 [52] and phosphorylation of both residues is required for the optimal activation of Akt [31], we analyzed phosphorylation of serine 473 . After $0.5 \mathrm{~h}, \mathrm{c}_{2^{-}}$ ceramide treatment resulted in a rapid and substantial decrease in the signals corresponding to P-Ser ${ }^{473}$-Akt (Fig. $2 \mathrm{~A}$, first panel) without significantly affecting the level of total Akt (Fig. 2A, second panel). The ratio P-Akt/total Akt decreased very rapidly during $\mathrm{c}_{2}$-ceramide treatment and reached $15 \%$ of the control value after a 0.5 -h treatment, this low phosphorylation level remained throughout the apoptotic process (up to a 24-h treatment; Fig. 2B).

In contrast, a 0.5 -h co-treatment of $\mathrm{c}_{2}$-ceramide and IGFI caused a rapid and substantial increase in signals corresponding to P-Ser ${ }^{473}$-Akt (Fig. 2A, third panel) without significantly affecting the level of total Akt (Fig. 2A, fourth
A

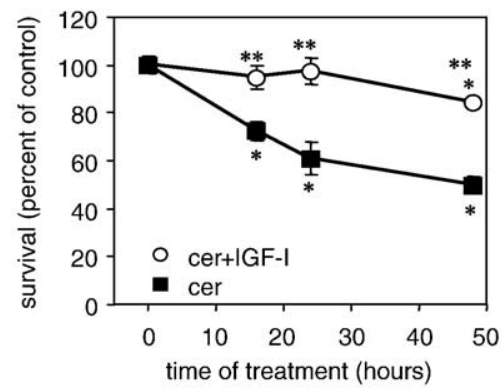

control
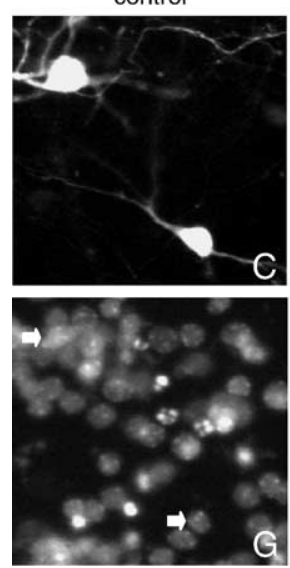

cer
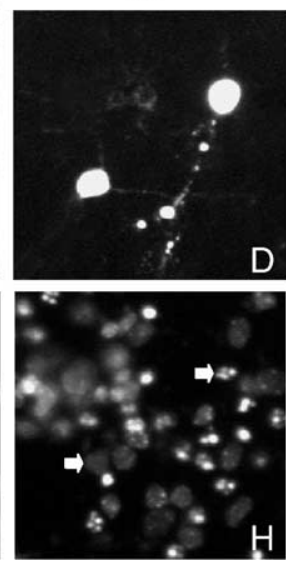

$\mathrm{B}$
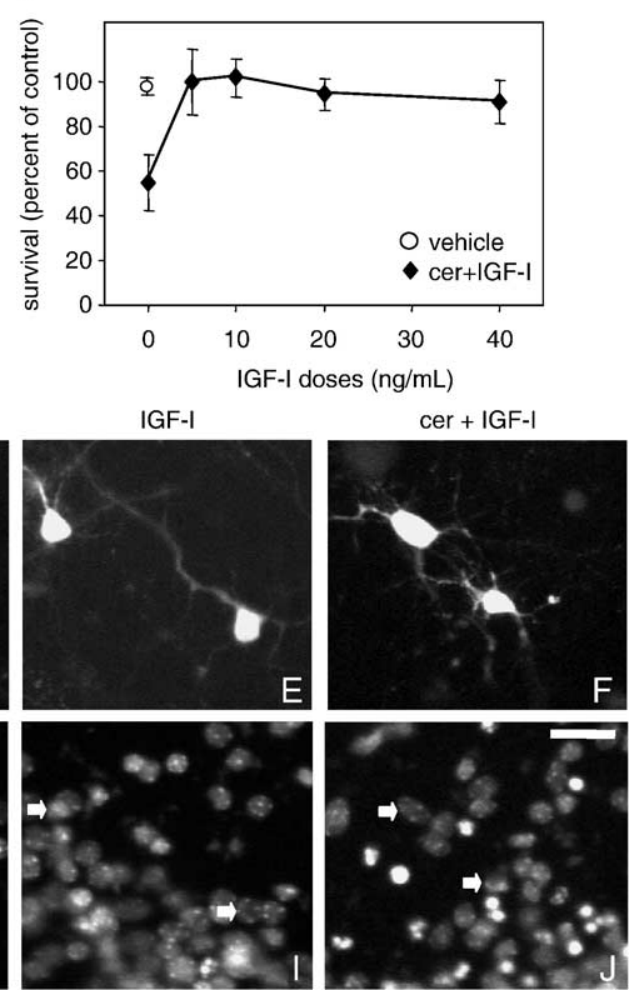

Fig. 1. IGF-I $(10 \mathrm{ng} / \mathrm{mL})$ protects cultured cortical neurons against $\mathrm{c}_{2}$-ceramide $(40 \mu \mathrm{M})$-induced neuronal death. The effect is time-(A) and-dose (B) dependent. Survival was assessed using the MTT assay. Data represent mean \pm SEM, $n=6$ independent experiments (A), $n=4$ independent experiments (B). ${ }^{*} P<0.05$ compared with the control value, according to the one-way ANOVA followed by Dunnett's post hoc test. $* * P<0.05$ compared with related ceramide value, according to the Student's $t$ test. (C-J) GFP visualization of transfected cortical neurons (C-F) and corresponding nuclei labeled with Hoechst $(\mathrm{G}-\mathrm{J})$, in control $(\mathrm{C}, \mathrm{G})$, $\mathrm{c}_{2}$-ceramide treated $(40 \mu \mathrm{M}$; D, F, H, J), and/or IGF-I treated $(10 \mathrm{ng} / \mathrm{mL}$; E, F, I, J) neurons after $24 \mathrm{~h}$ of treatment. White arrows: nuclei corresponding to GFP transfected cells. Scale bar: $20 \mu \mathrm{M}$. 
A

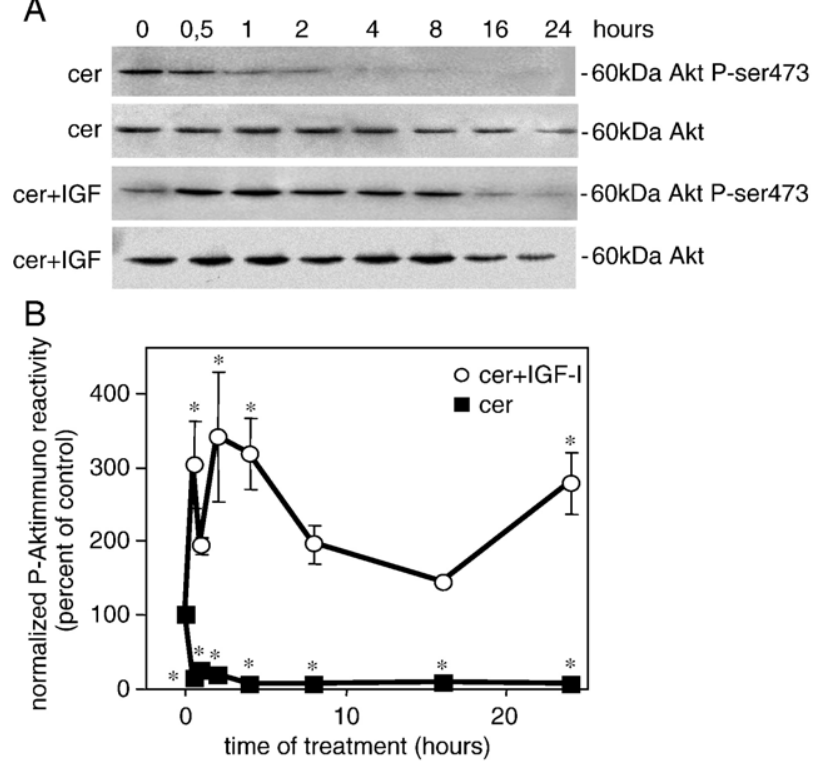

C

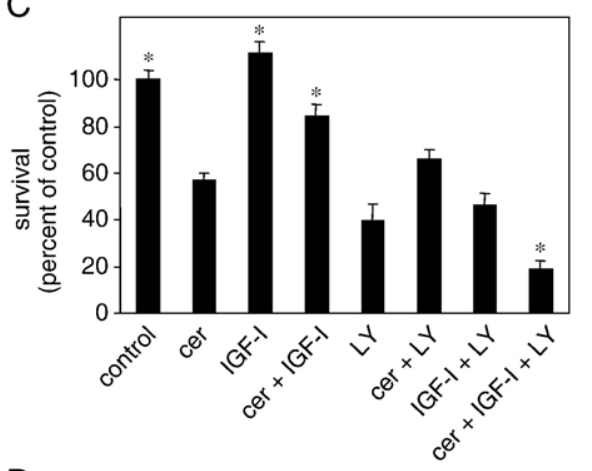

D

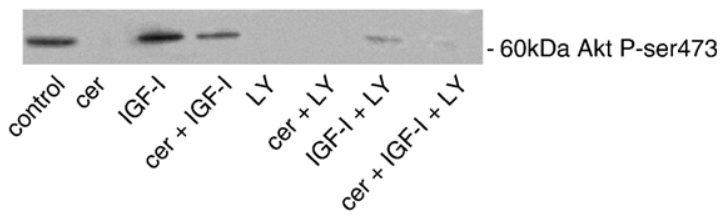

Fig. 2. IGF-I protection of cortical neurons implicates PI-3K/Akt pathway. (A) Immunoblot analysis of P-Akt (first and third panels) and total Akt (second and fourth panels) in extracts of $\mathrm{c}_{2}$-ceramide $(40 \mu \mathrm{M}$; first and second panels) or $\mathrm{c}_{2}$-ceramide $(40 \mu \mathrm{M})$ and IGF-I $(10 \mathrm{ng} / \mathrm{mL}$; third and fourth panels)-treated cortical neurons. (B) Quantification of P-Akt immunoreactivity during $\mathrm{c}_{2}$-ceramide $(40 \mu \mathrm{M})$ or $\mathrm{c}_{2}$-ceramide $(40 \mu \mathrm{M})$ and IGF-I $(10 \mathrm{ng} / \mathrm{mL})$ treatment. P-Akt signals were normalized to the corresponding total Akt signals. Data represent mean \pm SEM, $n=3$ independent experiments. ${ }^{*} P<0.05$ compared with the control value, according to the one-way ANOVA followed by Dunnett's post hoc test. (C) The PI-3K inhibitor LY294002 decreases survival. Survival measures were obtained after $24 \mathrm{~h}$ of LY294002 $(50 \mu \mathrm{M})$, IGF-I $(10 \mathrm{ng} / \mathrm{mL})$ and $/ \mathrm{or}^{\mathrm{c}_{2}-}$ ceramide $(40 \mu \mathrm{M})$ treatment. Survival was assessed using the MTT assay. Data represent mean \pm SEM, $n=4$ independent experiments. ${ }^{*} P<0.05$ compared with the $c_{2}$-ceramide value, according to the one-way ANOVA followed by Dunnett's post hoc test. (D) Immunoblot analysis of P-Akt in extracts of 7-h treated cortical neurons with LY294002 (50 $\mu \mathrm{M})$, IGF-I (10 $\mathrm{ng} / \mathrm{mL})$ and/or $\mathrm{c}_{2}$-ceramide $(40 \mu \mathrm{M})$ treatment as indicated.

panel). The ratio P-Akt/total Akt increased very rapidly during $\mathrm{c}_{2}$-ceramide and IGF-I co-treatment and reached $304 \%$ of the control values after a 0.5 -h treatment. This increase in phosphorylation level was maintained throughout the treatment (up to $24 \mathrm{~h}$; Fig. 2B). Inhibition of PI-3K by LY294002 abolishes IGF-I protection of cortical neurons against ceramide-induced apoptosis.

To determine whether the PI-3K/Akt pathway is involved in IGF-I protection against $\mathrm{c}_{2}$-ceramide-induced neuronal cell death, we applied the PI-3K inhibitor LY294002. This inhibitor is specific for PI-3K [13]. In Fig. 2C, ceramide decreased survival to $57 \%$ of the control and IGF-I protected neurons against ceramide-induced neuronal apoptosis, as detailed in Fig. 1. LY294002 $(50 \mu \mathrm{M})$ alone decreased survival to $40 \%$ of the control. LY294002 did not enhance ceramide-induced apoptosis after $24 \mathrm{~h}$ of treatment, but abolished IGF-I protection of cortical neurons against ceramide-induced neuronal apoptosis. Western blots of cellular extracts with the same treatments were performed with antibodies directed against the $\mathrm{Ser}^{473}$ phosphorylated form of Akt (Fig. 2D). We observe that when survival level was similar to the control value (control, IGF-I, cer+IGF-I), Akt was phosphorylated, whereas when apoptosis was induced (cer, LY, IGF-I+LY, cer+LY, cer+IGF-I+LY), the level of Akt phosphorylation was low or indetectable.

\subsection{Ceramide causes a decrease in CREB phosphorylation in cortical neurons}

As Akt may phosphorylate and activate CREB, we tested whether the phosphorylated form of CREB (P-CREB) was modulated during ceramide and/or IGF-I treatment. Western blot analyses of cellular extracts were performed after $7 \mathrm{~h}$ of treatment with ceramide and/or IGF-I (Fig. 3A), the time corresponding to the highest level of Akt phosphorylation during IGF-I and ceramide treatment, and also the minimum level of Akt phosphorylation during ceramide treatment alone (Fig. 2B). Ceramide treatment decreased CREB phosphorylation compared to control values, whereas IGFI treatment increased CREB phosphorylation. Thus IGF-I is able to induce CREB activity. However, when ceramide and IGF-I were applied in tandem, CREB phosphorylation decreased to the same level as the one after ceramide treatment alone. We also performed a more detailed kinetic analysis of P-CREB during ceramide and ceramide+IGF-I treatments, but there was no difference in the level of CREB phosphorylation at any time between both treatments (data not shown). Furthermore, we performed a P-CREB analysis after $1 \mathrm{~h}$ of the same different treatments as presented in Fig. $3 \mathrm{~A}$, and we got the exact same results as the one shown in Fig. 3A (data not shown).

Immunocytochemical detection of P-CREB confirmed these results (Figs. 3B-I). A basal level of P-CREB immunoreactivity was found in the nuclei of control cells (Figs. 3B and J), whereas after $7 \mathrm{~h}$ of $\mathrm{c}_{2}$-ceramide $(40 \mu \mathrm{M})$ treatment, P-CREB immunoreactivity was distinctly decreased (Figs. 3C and J). After IGF-I treatment, P-CREB immunoreactivity was increased (Figs. 3D and J), whereas ceramide+IGF-I treatment (Figs. 3E and J) decreased 
A
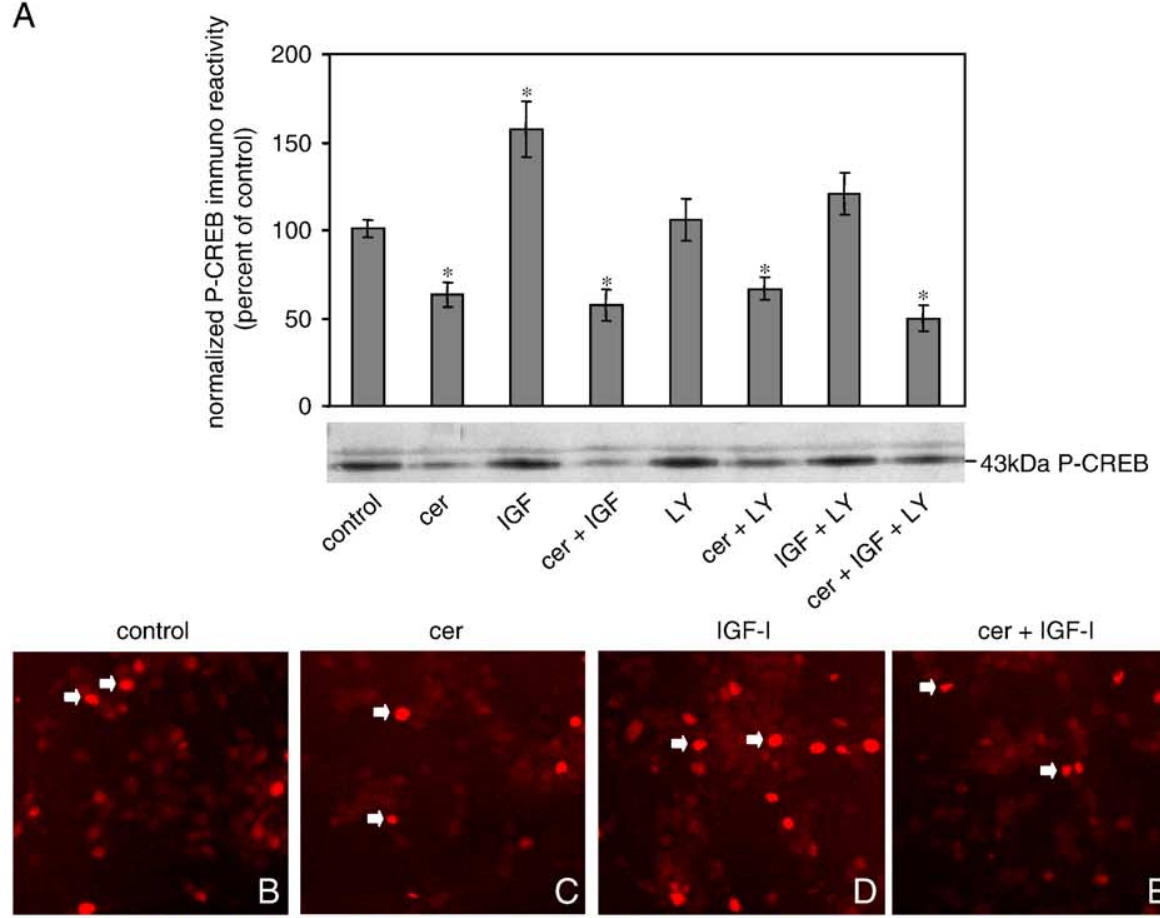

cer + IGF-I
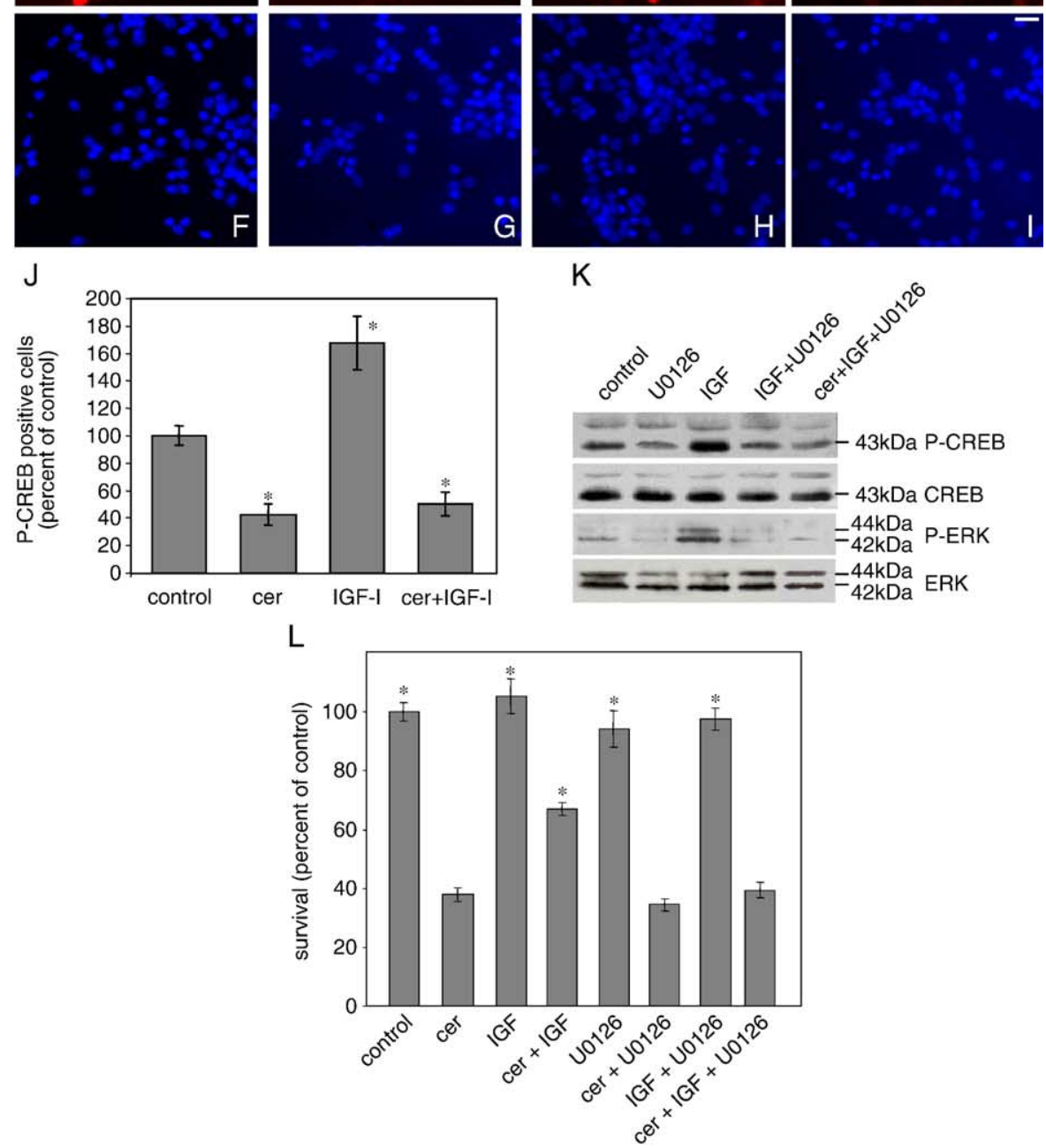
immunoreactivity to the level of ceramide treated cells. Thus, CREB phosphorylation is not involved in the IGF-I protection against ceramide-induced neuronal apoptosis.

\subsection{The PI-3K/Akt pathway is involved in IGF-I-induced phosphorylation of CREB}

To test if the PI-3K/Akt pathway is involved in CREB phosphorylation, we performed Western blot analyses of cellular extracts treated with ceramide, IGF-I and/or LY294002 during $7 \mathrm{~h}$ (Fig. 3A). These experiments revealed that LY294002 treatment alone, or in tandem with ceramide, had no effect on CREB phosphorylation. We also showed that LY294002 inhibited IGF-I induced-phosphorylation of CREB (compare IGF to IGF+LY treatments in Fig. 3A), but did not further decrease CREB phosphorylation after cer + IGF + LY treatment, compared to cer+IGF-I treatment. In conclusion, PI-3K is involved in IGF-induced phosphorylation of CREB but PI-3K inhibition is not involved in the basal phosphorylation of CREB, nor in CREB phosphorylation decrease induced by ceramide.

\subsection{The ERK pathway is involved in IGF-I-induced phosphorylation of CREB and in IGF-I-mediated protection of cortical neurons}

To investigate how ceramide antagonizes the stimulatory actions of IGF-I on CREB, we performed Western blot analyses of cellular extracts treated with IGF-I, $\mathrm{c}_{2}$-ceramide and/or the ERK pathway inhibitor, U0126, during $7 \mathrm{~h}$. We showed that IGF-I increases CREB phosphorylation (Figs. $3 \mathrm{~A}, \mathrm{~J}$ and $\mathrm{K}$ ), and that $\mathrm{U} 0126$ treatment decreases CREB phosphorylation, even in the presence of IGF-I (Fig. 3K). We also showed that IGF-I-induced ERK phosphorylation is abolished by U0126. In addition, we showed that ceramide or U0126, with or without IGF-I, induces a decrease in PCREB phosphorylation (Figs. 3A and $\mathrm{K}$ ). In conclusion, the ERK pathway is involved in the basal and in IGF-I-induced phosphorylation of CREB.

To see if the ERK pathway is also involved in the survival of cortical neurons, we performed survival experiments after treatment with IGF-I, $c_{2}$-ceramide and/or the ERK pathway inhibitor, U0126, during $24 \mathrm{~h}$. As we have already shown [60], inhibition of the ERK pathway does not
A

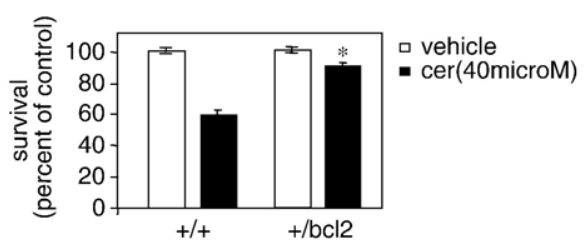

$\mathrm{B}$

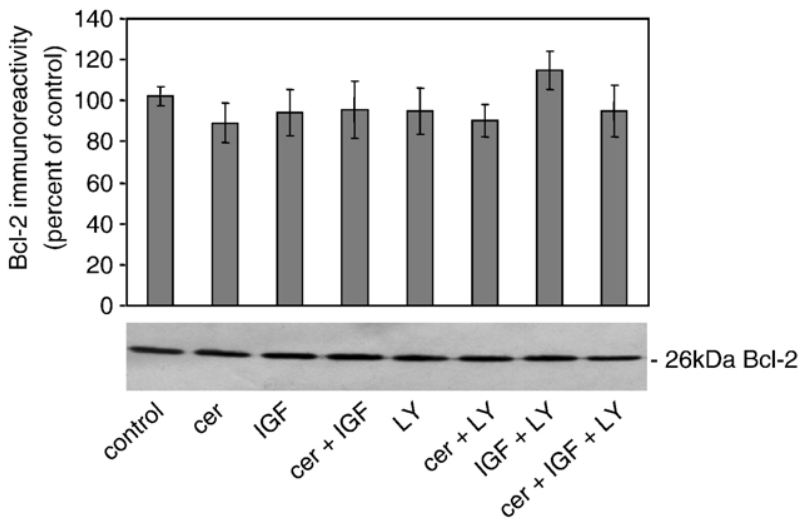

Fig. 4. (A) Survival after $24 \mathrm{~h}$ of $\mathrm{c}_{2}$-ceramide $(40 \mu \mathrm{M})$ treatment of cortical neurons from mice overexpressing $B c l-2$ and wild-type littermate. Survival was assessed counting viable cells with intact nuclei after Hoechst labeling. Data represent mean \pm SEM, $n=13$ independent experiments, $* P<0.05$ compared with wild-type (+/+) value, according to the Student's $t$ test. (B) Immunoblot analysis of $\mathrm{Bcl}-2$ in extracts of 7-h treated cortical neurons as indicated. Quantification of $\mathrm{Bcl}-2$ immunoreactivity during $\mathrm{c}_{2}$-ceramide (40 $\mu \mathrm{M})$, IGF-I $(10 \mathrm{ng} / \mathrm{mL})$ and/or LY294002 $(50 \mu \mathrm{M})$ treatment. Data represent mean \pm SEM, $n=5$ independent experiments. $P>0.05$ compared with the control value, according to the one-way ANOVA followed by Dunnett's post hoc test.

affect neuronal survival in control conditions, nor does it affect ceramide-induced apoptosis (Fig. 3L). We showed here that U0126 abolishes IGF-I-mediated protection against ceramide-induced apoptosis (compare cer+IGF and cer+IGF+U0126 in Fig. 3L). Thus, the ERK pathway is involved in IGF-I-mediated protection of cortical neurons against ceramide-induced apoptosis.

\subsection{Bcl-2 is not involved in cortical neurons protection against ceramide-induced apoptosis}

As the transcription factor CREB may regulate $b c l-2$ gene, we examined the effect of Bcl-2 on ceramide-induced apoptosis in primary cortical neurons from transgenic mice

\footnotetext{
Fig. 3. (A) Immunoblot analysis of P-CREB in extracts of 7-h treated cortical neurons as indicated. Quantification of P-CREB immunoreactivity during $\mathrm{c}_{2}-$ ceramide $(40 \mu \mathrm{M})$, IGF-I $(10 \mathrm{ng} / \mathrm{mL})$ and/or LY294002 $(50 \mu \mathrm{M})$ treatments. P-CREB signals were normalized to the corresponding total CREB signal (data not shown). Data represent mean $\pm \mathrm{SEM}, n=8$ independent experiments. $* P<0.05$ compared with the control value, according to the one-way ANOVA followed by Dunnett's post hoc test. (B-I) $\mathrm{C}_{2}$-ceramide induces a decrease of P-CREB in the nuclei of cultured cortical neurons. Neurons immunostained for P-CREB (red; B-E) and nuclear labeled by Hoechst (blue, F-I) in cortical cultures. Neurons control (B, F), treated with $\mathrm{c}_{2}$-ceramide $(40 \mu \mathrm{M} ; \mathrm{C}, \mathrm{E}, \mathrm{G}, \mathrm{I})$ or treated with IGF-I (10 ng/mL; D, E, H, I) during $7 \mathrm{~h}$. White arrows: examples of P-CREB positive cells. Scale bar: $20 \mu \mathrm{M}$. (J) Quantification of P-CREB positive cells from Figs. 4B-I immunocytochemistry experiments. Data represent mean $\pm \mathrm{SEM}, n=3$ independent experiments. ${ }^{*} P<0.05$ compared with the control value, according to the one-way ANOVA followed by Dunnett's post hoc test. (K) Immunoblot analysis of P-CREB, total CREB, P-ERK and total ERK in extracts of 7-h IGF-I $(10 \mathrm{ng} / \mathrm{mL}), \mathrm{c}_{2}$-ceramide $(40 \mu \mathrm{M})$ and/or ERK pathway inhibitor U0126 $(10 \mu \mathrm{M})$-treated cortical neurons. (L) IGF-I protection involves the ERK pathway. Survival measures were obtained after $24 \mathrm{~h}$ of U0126 $(10 \mu \mathrm{M})$, IGF-I $(10 \mathrm{ng} / \mathrm{mL})$ and $/ \mathrm{or}_{2}$-ceramide $(40 \mu \mathrm{M})$ treatment. Survival was assessed by counting viable cells after treatment with bisbenzimide. Data represent mean $\pm \mathrm{SEM}, n=15$ from 3 independent wells. ${ }^{*} P<0.05$ compared with the $\mathrm{c}_{2}$ ceramide value, according to the one-way ANOVA followed by Dunnett's post hoc test.
} 
expressing human $b c l-2$ and their wild-type littermate. After a 5-day maturation period in vitro, cultures were treated with $c_{2}$-ceramide $(40 \mu \mathrm{M})$ and assayed for cell viability 24 $\mathrm{h}$ after treatment by counting cells with normal nuclei labeled with bisbenzimide (Fig. 4A). Our results show that $b c l-2$ overexpression inhibited ceramide-induced apoptosis and protected cortical neurons: $91 \% \mathrm{bcl}-2$ overexpressing neurons survived compared to $59 \%$ of the wild type. Thus, $\mathrm{Bcl}-2$ protects cortical neurons against ceramide-induced apoptosis. The same cellular extracts as in Fig. 3A were submitted to Bcl-2 detection by Western blot (Fig. 4B). We showed that $\mathrm{Bcl}-2$ protein level was not modulated by ceramide, IGF-I, or LY294002. In all conditions tested, the $\mathrm{Bcl}-2$ protein level was comparable to the one of the control. We also performed a more detailed kinetic analysis of Bcl-2 during ceramide and ceramide $+\mathrm{IGF}$ treatments. As a result, we did not see any difference in the level of Bcl-2 protein at longer time points between both treatments (data not shown). Furthermore, we performed Bcl-2 analysis after 1 $\mathrm{h}$ of the same different treatments as presented in Fig. 4B, and we got the exact same results as the one shown in Fig. 4B (data not shown). Thus, although overexpression of Bcl2 protects cortical neurons against ceramide-induced apoptosis, there is no modulation of Bcl-2 protein level in IGF protection against ceramide-induced apoptosis.

\section{Discussion}

The objective of this study was to investigate the effects of IGF-I on ceramide-induced neuronal apoptosis, and the possible link between this molecule and the PI-3K/Akt/ $\mathrm{CREB} / \mathrm{Bcl}-2$ pathway in cortical neurons.

We showed for the first time that IGF-I protects cortical neurons from ceramide-induced apoptosis. IGF-I protection from ceramide has previously been shown in non-neuronal cells $[30,36]$. IGF-I has been also shown to protect hippocampal neurons from $\beta$-amyloid peptide toxicity [16], dorsal root ganglion neurons from Nerve Growth Factor withdrawal [59] and cortical neurons from hypoxia [58].

Pugazhenthi and his coworkers have proposed a link between IGF-I and the PI-3K/Akt/CREB/Bcl-2 pathway $[48,49]$. To test this hypothesis in cortical neurons, we analyzed Akt phosphorylation during ceramide treatment with or without IGF-I and PI-3K inhibitor. Using these different treatments, we have shown that when survival level was similar to the control value, Akt was phosphorylated, whereas when survival was low, Akt phosphorylation level was also low or undetectable. Thus, Akt seems to be a key enzyme for cortical neurons survival. A minimal activation of the PI-3K pathway is required for the survival of neurons; indeed, the levels of neuronal survival are in agreement with the immunoblotting raised against phosphoAkt (taken as a test of PI-3K activity) in the control situation and after treatment by LY alone: when PI-3K pathway is inhibited, the neuronal survival is decreased. The inhibition of Akt by ceramide may be mediated by several processes. Ceramide may decrease Akt phosphorylation by inhibiting PI-3K or PDK2, kinases upstream of Akt. This might be the case in our model, since (i) Akt has a low undetectable level of phosphorylation during ceramide treatment with or without LY294002; and (ii) IGF-I-induced phosphorylation of Akt has been shown to involve PI-3K and PDK2 $[14,25,43,46]$. However the intermediates between ceramide and PI-3K or PDK2 have not been identified yet. We cannot exclude other mechanisms for ceramide-decreasing Akt phosphorylation, such as dephosphorylation of Akt by a Protein Phosphatase-2A-like phosphatase (PP2A), Ceramide Activated Protein Phosphatase (CAPP) [51] or PKCל [5].

Since IGF-I and Akt promote neuronal survival, we examined a possible downstream effector, the transcription factor CREB. In accordance with previous results on nonneuronal cells $[47,49]$, we have shown for the first time in neurons, that IGF-I induced CREB phosphorylation via PI$3 \mathrm{~K}$ and ERK. However, our data demonstrate that CREB and Akt phosphorylations are not coupled, and that the neuronal survival is independent of CREB. Indeed, during ceramide and IGF-I treatment, neurons are protected, Akt phosphorylation increased but CREB phosphorylation decreased. Moreover, our experiments revealed that ERK is involved in the basal and in the IGF-I-induced phosphorylation of CREB. We also showed that IGF-I-mediated protection against ceramide-induced apoptosis involves the ERK pathway but not CREB. Thus, CREB is not linked to neuronal survival.

Our data showed that cortical neurons overexpressing Bcl-2 were protected from ceramide-induced apoptosis. A protective role of Bcl-2 from ceramide-induced apoptosis has previously been observed in two neuronal cell lines $[19,63]$ probably by blocking the release of cytochrome $c$ from the mitochondria into the cytosol [27,62]. However, immunoblotting experiments of $\mathrm{Bcl}-2$ showed that $\mathrm{Bcl}-2$ expression was not modulated during IGF-I, ceramide or LY294002 treatments. In consequence, Bcl-2 is not involved in IGF-I mediated protection. From this experiment we can conclude, that Akt does not act via CREB or Bcl-2 to protect neurons against ceramide-induced apoptosis. Akt may act on other proteins such as the transcription factor Forkhead or cytoplasmic proteins Bad, caspase-9 or IкB Kinase (for review see $[6,8,11]$ ). Moreover, a recent study shows that ceramide may act on Bad and Forkhead during neuronal apoptosis [55].

To summarize our results, in control conditions, the PI$3 \mathrm{~K} / \mathrm{Akt}$ pathway is involved in the survival of cortical neurons and the ERK pathway is involved in CREB phosphorylation. When neurons are treated with IGF-I, the ERK and PI-3K/Akt pathways are involved in CREB phosphorylation. When ceramide induces neuronal apoptosis, the ERK and PI-3K/Akt pathways, as well as CREB, are inhibited. We demonstrate for the first time that IGF-I protects neurons against ceramide-induced neuronal apopto- 
sis and that this protection involves the ERK and PI-3K/Akt pathways, but may be independent of CREB and Bcl-2.

\section{Acknowledgments}

We are grateful to C. Jarvis for critical review of the manuscript. This work was partially supported by grants from the French Association pour la Recherche sur le Cancer (to S.W.M.), France Alzheimer (to N.A.), and European Community (TMR Neuril FMRX CT97-0149 and Biomed Cybrainet BMH4 CT97-2492 to J.M.).

\section{References}

[1] D.R. Alessi, M. Andjelkovic, B. Caudwell, P. Cron, N. Morrice, P. Cohen, B.A. Hemmings, Mechanism of activation of protein kinase B by insulin and IGF-1, Embo J. 15 (1996) 6541-6551.

[2] D.R. Alessi, S.R. James, C.P. Downes, A.B. Holmes, P.R. Gaffney, C.B. Reese, P. Cohen, Characterization of a 3-phosphoinositidedependent protein kinase which phosphorylates and activates protein kinase Balpha, Curr. Biol. 7 (1997) 261-269.

[3] F.P. Altman, Tetrazolium salts and formazans, Prog. Histochem. Cytochem. 9 (1976) 1-56.

[4] A. Bielawska, H.M. Crane, D. Liotta, L.M. Obeid, Y.A. Hannun, Selectivity of ceramide-mediated biology. Lack of activity of erythrodihydroceramide, J. Biol. Chem. 268 (1993) 26226-26232.

[5] N.A. Bourbon, L. Sandirasegarane, M. Kester, Ceramide-induced inhibition of Akt is mediated through protein kinase Czeta: implications for growth arrest, J. Biol. Chem. 277 (2002) 3286-3292.

[6] D.P. Brazil, B.A. Hemmings, Ten years of protein kinase B signalling a hard Akt to follow, Trends Biochem. Sci. 26 (2001) 657-664.

[7] B. Brugg, P.P. Michel, Y. Agid, M. Ruberg, Ceramide induces apoptosis in cultured mesencephalic neurons, J. Neurochem. 66 (1996) $733-739$

[8] A. Brunet, S.R. Datta, M.E. Greenberg, Transcription-dependent and independent control of neuronal survival by the PI3K-Akt signaling pathway, Curr. Opin. Neurobiol. 11 (2001) 297-305.

[9] M.H. Cardone, N. Roy, H.R. Stennicke, G.S. Salvesen, T.F. Franke, E. Stanbridge, S. Frisch, J.C. Reed, Regulation of cell death protease caspase-9 by phosphorylation, Science 282 (1998) 1318-1321.

[10] S.R. Datta, H. Dudek, X. Tao, S. Masters, H. Fu, Y. Gotoh, M.E. Greenberg, Akt phosphorylation of BAD couples survival signals to the cell-intrinsic death machinery, Cell 91 (1997) 231-241.

[11] S.R. Datta, A. Brunet, M.E. Greenberg, Cellular survival: a play in three Akts, Genes Dev. 13 (1999) 2905-2927.

[12] W.H. Daughaday, A. Solomon, Berson 1918-1972, Trans. Assoc. Am. Physicians 85 (1972) 9-10.

[13] S.P. Davies, H. Reddy, M. Caivano, P. Cohen, Specificity and mechanism of action of some commonly used protein kinase inhibitors, Biochem. J. 351 (2000) 95-105.

[14] P. De Meyts, B. Wallach, C.T. Christoffersen, B. Urso, K. Gronskov, L.J. Latus, F. Yakushiji, M.M. Ilondo, R.M. Shymko, The insulin-like growth factor-I receptor. Structure, ligand-binding mechanism and signal transduction, Horm. Res. 42 (1994) 152-169.

[15] L. del Peso, M. Gonzalez-Garcia, C. Page, R. Herrera, G. Nunez, Interleukin-3-induced phosphorylation of BAD through the protein kinase Akt, Science 278 (1997) 687-689.

[16] S. Dore, S. Kar, R. Quirion, Insulin-like growth factor I protects and rescues hippocampal neurons against beta-amyloid- and human amylin-induced toxicity, Proc. Natl. Acad. Sci. U. S. A. 94 (1997) $4772-4777$.

[17] M. Dubois-Dauphin, H. Frankowski, Y. Tsujimoto, J. Huarte, J.C.
Martinou, Neonatal motoneurons overexpressing the bcl-2 protooncogene in transgenic mice are protected from axotomy-induced cell death, Proc. Natl. Acad. Sci. U. S. A. 91 (1994) 3309-3313.

[18] H. Dudek, S.R. Datta, T.F. Franke, M.J. Birnbaum, R. Yao, G.M. Cooper, R.A. Segal, D.R. Kaplan, M.E. Greenberg, Regulation of neuronal survival by the serine-threonine protein kinase Akt [see comments], Science 275 (1997) 661-665.

[19] C. Esdar, S. Milasta, A. Maelicke, T. Herget, Differentiationassociated apoptosis of neural stem cells is effected by Bcl-2 overexpression: impact on cell lineage determination, Eur. J. Cell Biol. 80 (2001) 539-553.

[20] V. France-Lanord, B. Brugg, P.P. Michel, Y. Agid, M. Ruberg, Mitochondrial free radical signal in ceramide-dependent apoptosis: a putative mechanism for neuronal death in Parkinson's disease, J. Neurochem. 69 (1997) 1612-1621.

[21] T.F. Franke, S.I. Yang, T.O. Chan, K. Datta, A. Kazlauskas, D.K. Morrison, D.R. Kaplan, P.N. Tsichlis, The protein kinase encoded by the Akt proto-oncogene is a target of the PDGF-activated phosphatidylinositol 3-kinase, Cell 81 (1995) 727-736.

[22] J. Guan, C. Williams, M. Gunning, C. Mallard, P. Gluckman, The effects of IGF-1 treatment after hypoxic-ischemic brain injury in adult rats, J. Cereb. Blood Flow Metab. 13 (1993) 609-616.

[23] Y.A. Hannun, Functions of ceramide in coordinating cellular responses to stress, Science 274 (1996) 1855-1859.

[24] P.J. Hartfield, G.C. Mayne, A.W. Murray, Ceramide induces apoptosis in PC12 cells, FEBS Lett. 401 (1997) 148-152.

[25] R. Kapeller, L.C. Cantley, Phosphatidylinositol 3-kinase, Bioessays 16 (1994) $565-576$.

[26] J.C. Kawamoto, J.N. Barrett, Cryopreservation of primary neurons for tissue culture, Brain Res. 384 (1986) 84-93.

[27] R.M. Kluck, E. Bossy-Wetzel, D.R. Green, D.D. Newmeyer, The release of cytochrome $c$ from mitochondria: a primary site for Bcl-2 regulation of apoptosis, Science 275 (1997) 1132-1136.

[28] B. Knusel, P.P. Michel, J.S. Schwaber, F. Hefti, Selective and nonselective stimulation of central cholinergic and dopaminergic development in vitro by nerve growth factor, basic ${ }^{\circledR}$ broblast growth factor, epidermal growth factor, insulin and the insulin-like growth factors I and II, J. Neurosci. 10 (1990) 558-570.

[29] R. Kolesnick, D.W. Golde, The sphingomyelin pathway in tumor necrosis factor and interleukin-1 signaling, Cell 77 (1994) 325-328.

[30] T. Kondo, T. Kitano, K. Iwai, M. Watanabe, Y. Taguchi, T. Yabu, H. Umehara, N. Domae, T. Uchiyama, T. Okazaki, Control of ceramideinduced apoptosis by IGF-1: involvement of PI-3 kinase, caspase-3 and catalase, Cell Death Differ. 9 (2002) 682-692.

[31] S. Kumari, X. Liu, T. Nguyen, X. Zhang, S.R. D’Mello, Distinct phosphorylation patterns underlie Akt activation by different survival factors in neurons, Brain Res. Mol. Brain Res. 96 (2001) 157-162.

[32] N. Lambeng, P.P. Michel, B. Brugg, Y. Agid, M. Ruberg, Mechanisms of apoptosis in PC12 cells irreversibly differentiated with nerve growth factor and cyclic AMP, Brain Res. 821 (1999) 60-68.

[33] G.M. Leinninger, C. Backus, M.D. Uhler, S.I. Lentz, E.L. Feldman, Phosphatidylinositol 3-kinase and Akt effectors mediate insulin-like growth factor-I neuroprotection in dorsal root ganglia neurons, FASEB J. 18 (13) (2004) 1544-1546.

[34] M.E. Lewis, N.T. Neff, P.C. Contreras, D.B. Stong, R.W. Oppenheim, P.E. Grebow, J.L. Vaught, Insulin-like growth factor-I: potential for treatment of motor neuronal disorders, Exp. Neurol. 124 (1993) $73-88$.

[35] L. Li, R.W. Oppenheim, M. Lei, L.J. Houenou, Neurotrophic agents prevent motoneuron death following sciatic nerve section in the neonatal mouse, J. Neurobiol. 25 (1994) 759-766.

[36] L.A. Maile, Z.P. Gill, C.M. Perks, J.M. Holly, The role of cell surface attachment and proteolysis in the insulin-like growth factor (IGF)independent effects of IGF-binding protein-3 on apoptosis in breast epithelial cells, Endocrinology 140 (1999) 4040-4045.

[37] J.C. Martinou, M. Dubois-Dauphin, J.K. Staple, I. Rodriguez, H. Frankowski, M. Missotten, P. Albertini, D. Talabot, S. Catsicas, C. 
Pietra, J. Huarte, Overexpression of Bcl-2 in transgenic mice protects neurons from naturally occurring cell death and experimental ischemia, Neuron 13 (1994) 1017-1030.

[38] S. Mathias, L.A. Pena, R.N. Kolesnick, Signal transduction of stress via ceramide, Biochem. J. 335 (1998) 465-480.

[39] T.M. Miller, M.G. Tansey, E.M. Johnson Jr., D.J. Creedon, Inhibition of phosphatidylinositol 3-kinase activity blocks depolarization- and insulin-like growth factor I-mediated survival of cerebellar granule cells, J. Biol. Chem. 272 (1997) 9847-9853.

[40] J. Mitoma, M. Ito, S. Furuya, Y. Hirabayashi, Bipotential roles of ceramide in the growth of hippocampal neurons: promotion of cell survival and dendritic outgrowth in dose- and developmental stagedependent manners, J. Neurosci. Res. 51 (1998) 712-722.

[41] M. Nakane, M. Kubota, T. Nakagomi, A. Tamura, H. Hisaki, H. Shimasaki, N. Ueta, Lethal forebrain ischemia stimulates sphingomyelin hydrolysis and ceramide generation in the gerbil hippocampus, Neurosci. Lett. 296 (2000) 89-92.

[42] N.T. Neff, D. Prevette, L.J. Houenou, M.E. Lewis, M.A. Glicksman, Q.W. Yin, R.W. Oppenheim, Insulin-like growth factors: putative muscle-derived trophic agents that promote motoneuron survival, J. Neurobiol. 24 (1993) 1578-1588.

[43] E. Nishida, Y. Gotoh, The MAP kinase cascade is essential for diverse signal transduction pathways, Trends Biochem. Sci. 18 (1993) $128-131$.

[44] G. Nunez, L. del Peso, Linking extracellular survival signals and the apoptotic machinery, Curr. Opin. Neurobiol. 8 (1998) 613-618.

[45] L.M. Obeid, C.M. Linardic, L.A. Karolak, Y.A. Hannun, Programmed cell death induced by ceramide, Science 259 (1993) 1769-1771.

[46] S.L. Pelech, J.S. Sanghera, Mitogen-activated protein kinases: versatile transducers for cell signaling, Trends Biochem. Sci. 17 (1992) 233-238.

[47] S. Pugazhenthi, T. Boras, D. O’Connor, M.K. Meintzer, K.A. Heidenreich, J.E. Reusch, Insulin-like growth factor I-mediated activation of the transcription factor cAMP response element-binding protein in PC12 cells. Involvement of p38 mitogen-activated protein kinase-mediated pathway, J. Biol. Chem. 274 (1999) 2829-2837.

[48] S. Pugazhenthi, E. Miller, C. Sable, P. Young, K.A. Heidenreich, L.M. Boxer, J.E. Reusch, Insulin-like growth factor-I induces bcl-2 promoter through the transcription factor cAMP-response elementbinding protein, J. Biol. Chem. 274 (1999) 27529-27535.

[49] S. Pugazhenthi, A. Nesterova, C. Sable, K.A. Heidenreich, L.M. Boxer, L.E. Heasley, J.E. Reusch, Akt/protein kinase B up-regulates Bcl-2 expression through cAMP-response element-binding protein, J. Biol. Chem. 275 (2000) 10761-10766.

[50] J.W. Russell, A.J. Windebank, A. Schenone, E.L. Feldman, Insulinlike growth factor-I prevents apoptosis in neurons after nerve growth factor withdrawal, J. Neurobiol. 36 (1998) 455-467.

[51] M. Salinas, R. Lopez-Valdaliso, D. Martin, A. Alvarez, A. Cuadrado,
Inhibition of $\mathrm{PKB} / \mathrm{Akt1}$ by $\mathrm{C} 2$-ceramide involves activation of ceramide-activated protein phosphatase in $\mathrm{PC} 12$ cells, Mol. Cell Neurosci. 15 (2000) 156-169.

[52] K.M. Schubert, M.P. Scheid, V. Duronio, Ceramide inhibits protein kinase B/Akt by promoting dephosphorylation of serine 473, J. Biol. Chem. 275 (2000) 13330-13335.

[53] T.F. Slater, B. Sawyer, U. Sträuli, Studies on succinate-tetrazolium reductase systems, Biochim. Biophys. Acta 77 (1963) 383-393.

[54] M.W. Spence, J.K. Burgess, Acid and neutral sphingomyelinases of rat brain. Activity in developing brain and regional distribution in adult brain, J. Neurochem. 30 (1978) 917-919.

[55] B.A. Stoica, V.A. Movsesyan, P.M.T. Lea, A.I. Faden, Ceramideinduced neuronal apoptosis is associated with dephosphorylation of Akt, BAD, FKHR, GSK-3beta, and induction of the mitochondrialdependent intrinsic caspase pathway, Mol. Cell Neurosci. 22 (2003) $365-382$

[56] M. Tagami, K. Ikeda, Y. Nara, H. Fujino, A. Kubota, F. Numano, Y. Yamori, Insulin-like growth factor-1 attenuates apoptosis in hippocampal neurons caused by cerebral ischemia and reperfusion in stroke-prone spontaneously hypertensive rats, Lab. Invest. 76 (1997) 613-617.

[57] M. Tagami, K. Yamagata, Y. Nara, H. Fujino, A. Kubota, F. Numano, Y. Yamori, Insulin-like growth factors prevent apoptosis in cortical neurons isolated from stroke-prone spontaneously hypertensive rats, Lab. Invest. 76 (1997) 603-612.

[58] M. Tamatani, S. Ogawa, M. Tohyama, Roles of Bcl-2 and caspases in hypoxia-induced neuronal cell death: a possible neuroprotective mechanism of peptide growth factors, Brain Res. Mol. Brain Res. 58 (1998) 27-39.

[59] R.S. Westphal, K.A. Anderson, A.R. Means, B.E. Wadzinski, A signaling complex of $\mathrm{Ca} 2+$-calmodulin-dependent protein kinase IV and protein phosphatase 2A, Science 280 (1998) 1258-1261.

[60] S. Willaime, P. Vanhoutte, J. Caboche, Y. Lemaigre-Dubreuil, J. Mariani, B. Brugg, Ceramide-induced apoptosis in cortical neurons is mediated by an increase in p38 phosphorylation and not by the decrease in ERK phosphorylation, Eur. J. Neurosci. 13 (2001) 2037-2046.

[61] S. Willaime-Morawek, K. Brami-Cherrier, J. Mariani, J. Caboche, B. Brugg, C-jun N-terminal kinases/c-Jun and p38 pathways cooperate in ceramide-induced neuronal apoptosis, Neuroscience 119 (2003) 387-397.

[62] J. Yang, X. Liu, K. Bhalla, C.N. Kim, A.M. Ibrado, J. Cai, T.I. Peng, D.P. Jones, X. Wang, Prevention of apoptosis by Bcl-2: release of cytochrome $c$ from mitochondria blocked, Science 275 (1997) $1129-1132$.

[63] H. Zhou, X.M. Li, J. Meinkoth, R.N. Pittman, Akt regulates cell survival and apoptosis at a postmitochondrial level, J. Cell Biol. 151 (2000) $483-494$. 